\title{
Regulated Medical Product
}

National Cancer Institute

\section{Source}

National Cancer Institute. Regulated Medical Product. NCI Thesaurus. Code C54695.

An article subject to the jurisdiction of the Food and Drug Administration, including any food or drug as defined in section 201(g) of the Federal Food, Drug, and Cosmetic Act (Act), any device intended for human or animal use as defined in section 201(h) of the Act, any cosmetic and biologic (as defined in section 351(a) of the Public Health Service Act (42 U.S.C. 262(a)) intended for human use, and any item subject to a quarantine regulation under part 1240 of chapter I of Code of Federal Regulations Title 21, Volume 1. 